\title{
CS-06 - Beneficios socieconómicos de las familias que pertenecen a las concesiones forestales comunitarias en Petén, Guatemala
}

\author{
Socioecomonic Benefits of families belonging to community forestry con- \\ cessions in Petén, Guatemala
}

*Amilcar Rolando Corzo Marquez, Deysi Lisbeth Rodríguez Max

Centro Universitario de Petén, Universidad de San Carlos de Guatemala

*Autor al que se dirige la correspondencia: amilcar.corzo@gmail.com

\section{Resumen}

L as concesiones forestales comunitarias creadas en la década de los años noventa del siglo pasado, son una estrategia de conservación en la Reserva de la Biósfera Maya. La evidencia de monitoreo sobre la cobertura boscosa indica un impacto positivo en la conservación de los bosques. El estudio analiza el impacto socioeconómico a nivel del hogar en los grupos concesionarios comparándolos con grupos sin concesión. La evidencia indica que,aunque el efecto no es muy grande, los grupos que pertenecen a las concesiones tienen mayores ingresos, mejores condiciones de hogar, acceso a servicios de salud, mayor acceso a educación y percepciones sobre los recursos naturales y su conservación más afines a la teoría conservacionista. Pese a que hay diferencias socioeconómicas a favor de las concesiones, el acceso a esos beneficios es menor en las concesiones que se encuentran dentro de la Reserva, en contraposición a los grupos concesionarios urbanos que viven fuera de ella.

Palabras clave: forestería comunitaria, conservación, cobertura forestal, áreas protegidas, biósfera maya.

\section{Abstract}

Community forest concessions (CFCs) created in the decade of the 90s years are a conservation strategy used

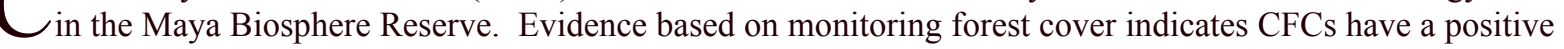
impact on forest conservation. This study analyzes and compares the socio-economic impact of CFC membership with non-CFC membership at the household level. The evidence indicates that although the impact if not great, households belonging to a CFC do have higher incomes, better home conditions, better access to health services and education, and have perceptions about conservation of natural resources that are more in line with conservation theory than non-member households. Although there are socio-economic differences favoring concession membership, access to these benefits are less for member households residing within the Reserve than for urban member households residing outside the Reserve.

Keywords: Community forestry, conservation, forest cover, protected areas, Mayan biosphere. 